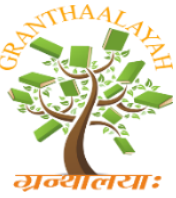

Social

\author{
INTERNATIONAL JOURNAL OF RESEARCH - \\ GRANTHAALAYAH \\ A knowledge Repository
}

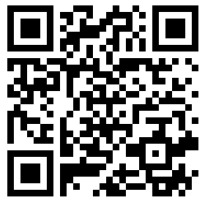

\title{
APPLICABILITY OF MASLOW'S THEORY ON CONSTRUCTION WORKERS
}

\author{
S Radhakrishnan ${ }^{1}$, Dr K G Selvan ${ }^{2}$ \\ ${ }^{1}$ PhD Research Scholar, PRIST University, Thanjavur 613 403, Tamil Nadu, India. \\ 2 Professor, PRIST School of Business, PRIST University, Thanjavur 613 403, Tamil Nadu, \\ India
}

\begin{abstract}
India is literally galloping in Industrial Development. The traditional identity of agrarian economy is superseded by rapid industrialization. The country accords top priority for industrial growth. We have a commendable presence in World Trade Organization as well. India is considered as the mouthpiece of developing nations.

Multinational Companies evince keen interest in having joint venture with Indian Corporates. They consider India as the safe platform for their industrial investment here.

This, appreciably promotes employment opportunities in the country. People from rural areas move to urban areas seeking employment. The industrial pay structure is also reasonable enough enabling people have a good disposable income.

The accumulation of people in the city necessitates more of living space in the city. The rental cost in the city is getting dearer.

This results in construction of more number of apartments in multi storied buildings in the city and the outskirts of same.

Another important thing that deserves mention is the easily available long term institutional finance for youngsters. They prefer to buy an apartment rather than going in for rental accommodation as, in comparison, the EMI is much better than paying rent which does not give them any benefit at all.
\end{abstract}

Keywords: Site Condition; Workers’ Needs; Safety Concerns; Motivation.

Cite This Article: S Radhakrishnan, Dr K G Selvan. (2019). “APPLICABILITY OF MASLOW'S THEORY ON CONSTRUCTION WORKERS." International Journal of Research Granthaalayah, 7(5), 245-255. https://doi.org/10.29121/granthaalayah.v7.i5.2019.844.

\section{Introduction}

Personal visit to individual sites. Observation and Discussion Methods. 


\begin{tabular}{|l|l|}
\hline Contours & Details \\
\hline No. of sites visited & 3 \\
\hline No. of floors & 3,4 and 6 \\
\hline Statutory Compliance & Fully complied \\
\hline RERA Approval & Obtained \\
\hline Female Workers & Present in First, Negligible in Second and Nil in Third \\
\hline Safety Concerns & Poor in First, Moderate in Second and Superb in Third \\
\hline Migrated Workers & Present in second site. \\
\hline Handling of Workers & Rough in First, Not bad in Second and Fine in Third \\
\hline $\begin{array}{l}\text { Performance of } \\
\text { Workers }\end{array}$ & $\begin{array}{l}\text { Not too good in First, Average in Second and Quite Committed in } \\
\text { Third }\end{array}$ \\
\hline Motivation & Nil in First, Present in Second and Splendid in Third \\
\hline
\end{tabular}

\section{What is Need?}

Need is an urging feeling. It is both physical and mental. The degree of that varies from person to person according to the circumstances they are in. A need that is satisfied relieves a person from nagging feeling and that is suppressed or ignored makes them think over the same again and again resulting in restlessness.

This makes them behave in a rather queer manner, unmindful of what they are doing.

The need is playing a pivotal role in the human life.

\section{Nature of Construction Workers}

The construction workers are basically people of brown than brain. They are prepared to put in any amount of efforts in their work. If they are annoyed, the outcome will be quite unpleasant. If they are patted, definitely, the result is marvellous.

In dealing with workers, particularly, construction workers, the Site In Charge/Site Engineer must show humane approach. Their behaviour is instant in reaction. A kind treatment will make them enslaved to the builder and work like a robot, without even bothered about the time aspect.

Contrary to the above, any annoyance caused will make them behave rather irritably and at times, to the level of even halting the work. The person handling construction workers must be ingenious. Their nature being what it is, they cannot bear even a slight harassment. If they feel they are harassed, they will literally pour a hell at the site and controlling them will become very difficult.

The psychology of workers is that they will always harbour at the deep of their mind that just because they are uneducated, they are forced to do a job like this and that an educated person is simply bossing over them, unmindful of their age.

When a young Site Engineer is instructing the workers or under the worst circumstances, questioning them, definitely it is like fanning the flame. They cannot control themselves in their reaction. It is a practical problem in any site. 
This was eminently displayed in the first site. It is just a small thing but led to a bitter quarrel.

The workers were served Tea. The quantity of tea was pretty less. The tea cup was tiny and it was like an ounce glass. Even in Tea Stall, they will give tea in a bigger cup (they call it as "Single").

The workers were grumbling at the quantity of the tea (which will be over in just two or three sips|) being served to them. On the day of the incident, the tea served was not hot enough and all the site workers started shouting at the Site In Charge. More like a war of words.

The Site In Charge, basically a hotly guy, was simply arguing with them brushing aside their just feelings. The Builder came in at that time to inspect the progress at the site.

All the aggrieved workers straightaway rushed towards him and made a loud complaint about the dirty behaviour of the Site In Charge. The builder was really shocked. Upon enquiry, he came to know that the Site In Charge was a very mean minded person and he was supplying only an ounce of tea (in the name of 'single tea') and was swindling the balance money. He warned sternly the Site In Charge.

He did not stop with that. He went one step further in making a sincere apology to the workers for the mistake. He assured them of hot tea and in right quantity. The workers were quite touched by the genuineness of the builder and became very emotional.

The issue may seem to be very simple or frivolous, but the impact it produced is really huge.

The Hierarchy Need Model of Maslow starts with Physiological Needs. These are the very basic needs that any individual requires for their very survival. It is beyond the status of the individuals. Whether they are rich or poor, educated or uneducated and a host of others like that.

These basic needs are called "Survival Needs" and are common to any living being.

An extension of this application shows that even the Site Engineers or the Project Managers, for that matter, the very well educated persons too, when they do such a strenuous job, it is but natural that they need some sort of hot drink (whether Tea or Coffee or any other drink) in required quantity to keep themselves fit for the work.

This works as a sort of stimulation to keep the tempo on in the work. If it is not given, an 'in explainable sense' of irritation will surface in their feelings and if it is continued, it will result in restlessness in mind and will produce negative feelings in their perception, expression and will end up in utter mess.

If the site workers, with whom only the construction goes on floor after floor, are ruptured, whatever be the reason, the negative impact of that will get resulted in the construction, irrespective of the supervision.

This is a case of Physiological needs, ie, the First of the Needs. 
Utmost care is to be bestowed in construction as, it is the considered opinion of the Civil Engineers, that any revision in work is only tantamount to weakening the structure. A wilful error in pipe laying will lead to refurbishing the whole work once again. This, besides leading to cost penalty to the builder, will weaken the structure as well.

The builder will finish the construction within the timescale and handover the apartments to the purchasers. The dwellers will only feel the brunt of the problem, after some time. This is the reason that eminent builders will never do or agree for any rework or alteration from the approved specification.

\section{Workplace Safety is Yet a Question Mark}

Construction work is not only laborious but also quite risky. In fact, more the number of floors, more the risk factors are. It is quite natural that the workers posted at the top floors are always gripped with a sort of fear either real or imaginary. They show passive resistance to work in top floors, but in vain.

The fear factor is dampening their contribution. It has a telling effect on their productivity. Many worksite accidents occur due to surge of fear in the minds of workers about their safety, though they would be protected with safety equipments. This is inevitable. With enormous activities taking place simultaneously, it is very difficult to be wary at all times. Even a genuine slip may prove costly.

In the second site, it was observed that the workers were doing their work sincerely, but there was an element of ingrained fear in their minds about their safety. A group of workers were arguing with the Site Engineer that personal protection equipments were not properly provided to them.

They expressed vertigo problem while performing the work. The Site Engineer ridiculed at them for the poor stamina they have. He further said that construction workers must possess a robust body and strong mind to face any arduous operating conditions.

The annoyed workers were quick in their reply. They were totally uncomfortable with the piece of wood as seat and the thick rope with which they were tied. They openly said that they did not have any uncomfortable feeling at all even when they were working on eighth or ninth floor where they were provided with steel chains and a cushion seat as Personal Protection Equipment (PPE).

In this regard, it is worthwhile noting that "falling from a height is the most common type of fatal accident in the Construction Industry".

The important point to be noted here is that the safety feelings play a predominant role in contributing or determining the productivity of the site workers.

It is true that fear dominated workers are sure to make mistakes. Simple mistakes can be easily set right whereas bigger mistakes will result in catastrophe. Fear erodes concentration and a kind of consternation engulfs them. This is enough for work site accidents. 
If the accidents are serious, the builder will be in trouble. Not only that, the site will be covered with a gloom and the other workers would only prefer to go away from that site to any other place. It is very easy to get job in construction industry and the reality is that the builders find it difficult to retain committed workers. This is equally true with labour contractors as well.

One other thing to be seen is that the name of the builder will also be sullied. If he is embroiled in court case, whatever be the verdict later on, the reputation of the builder would be at stake. Such information will spread like forest fire.

The prospective purchasers will think differently about the builder. If he cannot show commitment in saving the lives of his own workmen, what will be his commitment level to his Home Buyers. The question may have differing degree of acceptance. But, such a question, once crops up in the minds of people, they would only shelve the idea of buying an apartment from that Builder. He cannot change that stigma for quite some time.

The safety aspect is much to be desired in many places. Of course, eminent builders are exception to this.

Workers are also human beings and they too have the right to demand things that they need legitimately for the safety of their operation.

This incident amply proves the Maslow’s theory of Safety Needs.

\section{Migrated Labour}

In the field of construction, migrated labour find tremendous opportunities. Of course, next to agriculture, construction is the industry that offers job opportunities to people of all walks of life.

In the second site, considerable number of migrated labour was noticed. Their commitment level, if it is to be said quite openly, was found much more than that of locals.

The migrated labour are always gripped with some fear about job security and hence are prepared to even stay back willingly to finish the work, without any specific demand from the Site Engineer. Basically, they are cautious (or afraid, for that matter) of job security.

The common feeling of locals is that if they are unhappy in one site, they can easily go to some other site, as construction workers are in great demand, generally.

The nature of being local gives them a feeling of superiority, added further with a bit of impudence, too.

Their movement with migrated labour is always guarded and with a distance.

In fact, the migrated labour were so friendly and wanted to mingle freely with the local workers at the site. But the local workers were only distancing themselves away from them. Except on work instructions and supervisory advice, they hardly spoke to them. 
The psychology plays predominant role here. The migrated labour come only in search of jobs. They show utmost commitment in whatever job they do - this is basically to cling to the job they are doing.

They always have, at the back of their mind, the utter straits they were in, in their mother state and the necessity to go away from their state in search of job for their very life. This automatically instils a commitment in their mind to do the work with full involvement. They are longing for recognition at the site.

They know pretty well that this will enable them retain their job throughout the project execution. Further, they know pretty well that they would also be hired for the subsequent projects based on their committed performance here.

This doubly ensures that they show unflinching commitment in the work to excel the locals, given an opportunity. This would enable them get preferential treatment form the builder also.

It has the other side impact as well. The locals develop a kind of enmity towards migrated labour. Their relations with them are always strained. They show a disdainful look at them, falsely thinking that they encroach on their employment.

At the site, they form groups and do the job. While the Builder or the Site Engineer do not harbour any unworthy feeling about the migrated labour, the co-workers always show unfriendly attitude. The sad thing is that they are waiting for opportunities to ditch them.

The migrated labours know all these pretty well, but they keep quite digesting all the harms inflicted on them. They do so just for the sake of sticking on to the job which is only giving them the livelihood.

They do conversation amongst themselves only. Occasionally, they are seen mingling with locals. They are always ready to be with them as a part but only the locals show them aversion.

The important point to be seen here is that all are equals in status. All of them are only site workers. They do the same job only. There is nothing significantly distinguishing them from one another.

When this being the case, how come there is a question of avoiding them. It is nothing but a perceived sense of fear that they would overtake them in quality of performance or getting preferential treatment from the contractor/builder and their representatives.

Going deeper in the analysis, we can deduce that they have a sense of fear that they (migrated labour) are their threats in the site. This root cause only produces ill will against them.

The issue is to be viewed from the other angle too. The migrated workers show unbelievable loyalty to the Boss and their performance is that of a bonded labour. They willingly do this only to be in the favourable books of the builder. 
The separation from their own State and being in a far flung area with language problem and other vital issues, they prefer to be quite accepting all the inflictions, just for their survival. At the same time, they also have their desire that they should be loved by the people around them.

They are craving for the love and affection of co-workers, particularly, from the ones, whose state they have come for their survival. Their rejection, drives them feel desperate.

The locals too, have the same urge in their mind. But, their superiority feeling drives it out of their mind. An imaginary fear about the migrated labour that they will eat away their job opportunities, given a chance to settle down at the site, is only the main reason for this.

With unbiased approach, one can conclude that Maslow's Theory of Social Needs is aptly recognised here. The persons, whose physiological needs and safety needs are fulfilled, always look out for a sense of love and affection from their fellow beings. This is more present at the work place.

Work place is only part of a society. And, of course, Society is only a congregation of people of all walks of life.

It is relevant to note that "when we work together, we encourage one another and build on each other's work, utilising our strengths and compensating for weaknesses. In short, a group does best when it makes the maximum use of each individual's contribution".

Hence, the Theory of Social Needs has relevance with every one and construction workers are no exception to that.

\section{Respect is Mandatory for Mutual Respect}

The third site was an outstanding one with all good qualities present in everything.

Commitment level was remarkable with everyone. The work instructions passed on to the site personnel, were faithfully adhered to. Supervision was very moderate as the people were quite aware of their role and responsibility.

The maintenance of the site was appreciable. More of construction machineries were put into use. Goes without saying that proper mix of men and machinery will always result in excellent output. Productivity of labour was quite good.

The work for the succeeding day was well planned and organised on the previous day itself. The Site Engineer was issuing instructions to the personnel to come half an hour earlier (taking into account the time they need to warm up themselves, before staring the work) the next day as cranes and other equipments would be coming to install the prefabricated concrete structures.

Since the prefabricated concrete structures are space consuming, the Site Engineer planned the activities in such a manner that the concrete structures, cranes and machineries were all planned 
to arrive at the same time. To top it all, he did it quite cleverly that the site personnel were required to be at the site with a ready to work mood, the moment all the above three arrive at the site.

This is where a smart Site Engineer cuts himself above the rest.

The Site Engineer was respected by everyone at the site. Not only the Site Personnel, but also the Vendors, Transporters and other people had good regards for him. A young Civil Engineer with full enthusiasm in work, inborn quality of respecting others, unbiased vision, he was respected by one and all at the site.

Perhaps, a correction can be made here - except one - and that one was the Project Manager.

The remarkable site, with all good qualities of how a construction site should be, was promoted by an eminent builder. He has Supply Chain Management for quite some time in practice and he treats his suppliers not as merely vendors but as Partners for Mutual Growth.

He shares all technical information with his suppliers in order to get the best from them. No wastage in supplies or no delays. The activities were going on in a military discipline.

These are, of course, the business traits and qualities of eminent builders. That's the reason they enjoy such a reputation in the field for decades.

As they outsource materials, they outsource labour as well from Labour Contractors. They have dependable Labour Contractors for years.

The builder has only minimum personnel at his permanent payroll. These people comprise Accounts personnel, Administration personnel, Site Engineers and Project Managers.

The builder is known for undertaking many projects simultaneously at different places. All the sites are posted with at least one Site Engineer. The site with more floors and more apartments have more than one Site Engineer.

As far as he Project Managers are concerned, they are only a few. A Project Manager has in his control, at least two projects as his role is more of supervision and advice.

In this remarkable site, the Site Engineer was also a remarkable person. He is not only well educated but also well mannered.

He is an expert in foreseeing the problems and taking proactive action. The Site In Charge made a very proud remark about the Site Engineer that after he came to the site, there was no wastage either in materials or waste hours due to non-availability or delayed availability of personnel.

At the young age, he possesses the wisdom of elderly person and his enthusiastic spirit enables him move with all the site personnel amicably. The Site Engineer fully deserves the generous appreciation of the Site In Charge and others. 
Here, it is necessary to note that "the success of a person depends upon not only how much he can work himself but also how much work he can get done from others"

He could get along well with everyone. Even a helper could have easy accessibility to him. People could freely voice their views to him - even on construction issues. Such was his friendliness and the liberty he gave his people.

The problem cropped up, probably, because of this.

The Project Manager, for whom the project under reference is also one under his control, developed jealousy over this young Site Engineer.

His elderly age fanned the flame. While he was compassionate with others, he took each and every opportunity in finding fault with the Site Engineer. Instead of guiding him, he was demotivating him, to his heart's content.

The Project Manager feared (which was purely imaginary) that this young Site Engineer would become his threat|. He could not find any reason to eliminate him and hence was only developing hatred towards him. Highly unfortunate.

The builder, who is also a Civil Engineer and has been in the profession for years, quickly grasped the situation. He knew the merit and mettle of that young Site Engineer. At the same, the Project Manager is also a highly knowledgeable person with tremendous experience, having completed many projects in a record time. He valued his age and experience as well.

He took a brilliant action. Since a Project Manager is controlling two to three projects, the Project Manager was relieved of this project and a different project was attached to him. Another Project Manager was brought in to take care of the project under reference.

The young Site Engineer is a highly knowledgeable engineer. He knows the art of getting the work done by the site personnel. He clearly distinguishes his style of performing with every one - form helper, site personnel to others (including the Owner Builder).

As he respected others, others too respected him out of sheer love and affection. As he was a master in his work, the respect of others doubled with awe. He was fully right and justified in his Esteem Needs. (Probably, this would have been the cause of irritation to the Project Manager).

This young Site Engineer is an outstanding example for the Maslow's theory of Esteem Needs.

\section{Was the Project Manager right in his Self-actualisation Needs?}

This is to be discussed without bias. The self-actualisation needs arise after all the other preceding needs have been fulfilled. In the case of the Project Manager under reference also, his previous needs have been fully fulfilled. He is also in the good books of the Builder. He has shown his great calibre in bringing out many projects in record time. 
No doubt that the Project Manager is a highly capable person and his talents cannot be questioned. The main draw back with this person is that he is a negative minded person.

He has developed imaginary fears in his mind that those who are equally capable like him, more particularly the youngsters, could eliminate him. This uncalled for fear has brought him all the displeasure in his mind.

This has forced the Project Manager to behave in an unwarranted way of a Fault Finder. He could not control his negative feelings which have overtaken him completely.

The builder may not like to send him off because the Project Manager has shown great credentials to the builder. No doubt, he is a man of talents. This is a different question.

From the point of view of others, he is only looked at as an "Abominable No Man". If he continued with this queer behaviour, definitely, he would have to even go out of job.

Had the Project Manager, a talented and experienced person, behaved in a more mature manner by guiding his people and motivating them, he would have been extolled as a Role Model by everyone in the organisation. People would have looked up to him for his valued advice.

In this context, let us get the sage advice - "Responsibility and Influence are twin tools without which good management is pretty well impossible to achieve. The art of managing people implies taking on responsibility. By giving them responsibility, you are enhancing their jobs and their lives".

This would have taken him to great heights and he could have also seen further advancements in his career with the builder.

What would have happened to him is a different question. But, certainly, had he continued with his negative approach, he would have been despised by all.

Self-actualisation needs arise only when all other needs have been fully met and a person should be extremely careful in this. In fact, for that matter, even the Esteem Needs, at times, take the people to a spin.

Too much of anxiety for recognition is negative ended. Unfulfilled expectations would result in desperation and would move the situation to further exacerbation.

\section{Conclusion}

Maslow's Theory of Need Hierarchy is applicable to any person in any field. Physiological Needs, Safety Needs and Social Needs are applicable widely to all the Construction Workers. The Esteem Needs would come in to the minds of people of higher order in the work site. The Site In Charge and Site Engineer may have aspirations to become next in the ladder. Self- actualisation needs too, have good relevance in construction industry and this is for the people of higher order who would be desiring to move to yet another higher status. 


\section{Recommendation}

Construction Industry is a risk prone industry. Chances of fatalities are higher in this. The people who work there must have their basic needs satisfactorily fulfilled. Physiological needs and Safety needs are pretty important. The builder should make no compromise in these. Troubled workers are enough to bring bad name to the builder. Their disgruntlement may have repercussions even in their construction. This is very dangerous.

Personal Protection Equipments must be provided to the site workers and they should be allowed to work only after they are fully prepared for the work.

A satisfied worker is an asset to the builder. Without looking at the clock, they would work like a robot. Anything is possible to workers, if they are properly handled. If they are ruffled, it would be topsy-turvy.

Motivation is quite necessary for the middle level - such as for Site In Charge and Site Engineers.

The person who is aspiring for Self actualisation needs should be sagacious enough for the same.

\section{References}

[1] Page no. 261, Book Name: The Manager's Guide to Health and Safety at Work $-8^{\text {th }}$ Edition. Author: Jeremy Stranks. First South Asian Edition 2007. Copyright @ Jeremy Stranks. 1990, 92, 94, 95, 97, 2001, 03 and 2006. Kogan Page Limited, 120, Pentonville Road, London N19JN - United Kingdom. Kogan Page India, 4737/23, Ansari Road, New Delhi 110 002. ISBN: 0 - $7494-4914-4$.

[2] Page no. 143, Book Name: Top Management Class - Lessons for Effectiveness. Authors: Richard Graham and Edwin Singer. Published by: Jaico Publishing Home, 121, Mahatma Gandhi Road, Mumbai 400 001. Published in Arrangement with Institute of Personnel Management, IMP House, Comp Road, Wimbledon, London, SW19 4UX. $\quad$ ISBN: 81 $7224-387-1$.

[3] Page No. 275, Book Name: Twelve Management Skills for Success, Author: Ram Narain. Copyright@Viva Books Private Limited, 2006, First Published 2006. Published by: Vinod Vasishtha for Viva Books Private Ltd, 4262/3, Ansari Road, Daryaganj, New Delhi 110 002. ISBN: $81-309-0184-6$.

[4] Page No. 93, Book Name: Managing People. Authors: Brian Clegg and Paul Birch. First Indian Edition 2009, Copy right @ Brian Clegg and Paul Birch. Published by: Kongan Page India Private Limited, 4737/23, Ansari Road, Daryaganj, New Delhi 110 002. ISBN: 10: $81-7554-431-7$ and ISBN: $13: 978-81-7554-431-4$.

\footnotetext{
*Corresponding author.
}

E-mail address: srk1960 @yahoo.in/drcsrv @gmail.com 